\section{Growth Responses of Fusarium oxysporum to Metabolites of Some Rhizospheric Microflora of Egyptian Cotton Varieties}

DURINe studies on the rhizospheric microflora of different cotton varieties grown in Egypt, Fusarium wilt-resistant Ashmouni cotton variety rhizosphere proved to be inhabited by the highest percentage of strains of Bacillus subtilis, while susceptible Giza 26 cotton variety rhizosphere contained the highest percentage of a strain of $B$. megatherium ${ }^{1}$.

Preliminary screening tests in which each of the bacterial strains was streaked against Fusarium oxysporum on either Dox's or soil-extract agar media have proved that $B$. subtilis strains were highly antagonistic to the wilt-inducing pathogen; the former spread rapidly and overgrew Fusarium mycelium and encircled it completely. Hyphæ of Fusarium were lysed and malformed. On the other hand, $B$. megatherium was stimulatory to Fusarium mycelial growth. The latter overgrew $B$. megatherium and produced comparatively very abundant conidia with abnormally large size and high septation.

Growth responses of Fusarium oxysporum, which proved to be a virulent pathogen causing wilt of either Karnak or Giza 26 cotton variety seedlings, to metabolites of either $B$. subtilis or $B$. megatherium on Dox's liquid medium have been tested by the following two methods : (1) germinative potentialities of Fusarium microconidia in hanging-drop cultures of either B. subtilis or B. megatherium metabolites; (2) growth of Fusarium mycelium on differently treated metabolites of either $B$. subtilis or $B$. megatherium. Filtrates of the test organisms were obtained from cultures of two ages, that is, 5- and 10-days old and were either cold-sterilized ${ }^{2}$ or autoclaved. Control solutions using either Dox's liquid or water were also used.

The results (Tables 1 and 2 ) show that considerable suppressed germination of Fusarium microconidia and mycelial growth took place in response to either 5 - or 10-days old culture filtrates of $B$. subtilis whether unheated or autoclaved. Ageing of culture or application of heat to its filtrate did not appreciably affect the latent period and final percentage of germination or the mycelial dry-weight of Fusarium. On the other hand, on using filtrates of $B$. megatherium from either 5- or 10-days old cultures, the final percentage germination of F'usarium microconidia rose to 100 per cent. At the same time, Fusarium mycelial growth was significantly higher as compared with that on control Dox's liquid media. A stimulatory factor for Fusarium microconidial germination and mycelial growth seems to be present in filtrates of $B$. megatherium the potency of which is not affected

Table 1. GROWTH RESPONSES OF Fusarium MICROCONPIA TO METABOLTH-FHTRATES OF Bacillus subtilis AND B. megatherium AT $30^{\circ} \mathrm{C}$.

\begin{tabular}{|c|c|c|c|c|}
\hline \multirow{2}{*}{$\begin{array}{l}\text { Experimental } \\
\text { medium }\end{array}$} & \multirow{2}{*}{$\begin{array}{l}\text { Age of } \\
\text { culture }\end{array}$} & \multirow{2}{*}{$\begin{array}{c}\text { Filtrate } \\
\text { treatment }\end{array}$} & \multicolumn{2}{|c|}{ Germinative capacities } \\
\hline & & & $\begin{array}{l}\text { Latent } \\
\text { period }\end{array}$ & $\begin{array}{l}\text { Germination } \\
\text { (per cent) }\end{array}$ \\
\hline $\begin{array}{c}B_{\text {. }} \text { subtilits } \\
\text { flltrate }\end{array}$ & $\begin{array}{l}5 \text { days } \\
10 \text { days }\end{array}$ & $\begin{array}{l}\text { unheated } \\
\text { autoclaved } \\
\text { unheated } \\
\text { autoclaved }\end{array}$ & $\begin{array}{l}5 \mathrm{hr} . \\
5 \mathrm{hr} . \\
5 \mathrm{hr} . \\
5 \mathrm{hr} .\end{array}$ & $\begin{array}{l}40 \\
40 \\
48 \\
50\end{array}$ \\
\hline $\begin{array}{l}B_{\text {. megatherium }} \\
\text { fltrate }\end{array}$ & $\begin{array}{l}5 \text { days } \\
10 \text { days }\end{array}$ & $\begin{array}{l}\text { unheated } \\
\text { autoclaved } \\
\text { unhested } \\
\text { autoclaved }\end{array}$ & $\begin{array}{l}5 \mathrm{hr} . \\
5 \mathrm{hr} . \\
5 \mathrm{hr} . \\
4 \mathrm{hr} .\end{array}$ & $\begin{array}{l}100 \\
100 \\
100 \\
100\end{array}$ \\
\hline Pure Dox's & - & - & $2 \mathrm{hr}$. & 90 \\
\hline Water & 一 & - & $3 \mathrm{hr}$. & 80 \\
\hline
\end{tabular}

Table 2. Fusarium MYCRLAY DAY Whight (IN MGM.) AFrRR 10 DAYS at $30^{\circ} \mathrm{C}$. IN RESPONSR TO DIFPBRBNTLY TRRATBD METABOLIC FinTRATES OF $B$. subtilis AND $B$. megatherium. PURE DOX's IIQUT IS DILUTED WITH WATER AND MEMABOLITE FILTRATES FITH PURE DOX's LIQUID

\begin{tabular}{|l|c|c|c|c|c|}
\hline \multirow{2}{*}{$\begin{array}{c}\text { Experimentel } \\
\text { medium }\end{array}$} & $\begin{array}{c}\text { Dilution } \\
\text { (per cent) }\end{array}$ & \multicolumn{3}{|c|}{$\begin{array}{c}\text { Filtrate from } \\
\text { 5-day old cultures }\end{array}$} \\
\cline { 3 - 6 } & & $\begin{array}{c}\text { Un- } \\
\text { heated }\end{array}$ & $\begin{array}{c}\text { Auto- } \\
\text { claved }\end{array}$ & $\begin{array}{c}\text { Un- } \\
\text { heated }\end{array}$ & $\begin{array}{c}\text { Auto- } \\
\text { claved }\end{array}$ \\
\hline $\begin{array}{l}\text { B. subtilis } \\
\text { flltrate }\end{array}$ & 100 & 33 & 35 & 29 & 30 \\
& 50 & 38 & 40 & 33 & 35 \\
B. mega- & 25 & 45 & 48 & 38 & 41 \\
therium & 100 & 40 & 43 & 38 & 42 \\
flltrate & 50 & 73 & 77 & 80 & 85 \\
\hline
\end{tabular}

- Mycelial dry weight on 100 per cent pure Dox's liquid, $75 \mathrm{mgm}$. Mycelial dry weight on 100 per cent pure Dox's liquid, 75 mgm.;
on 75 per cent Dox's liquid, 61 mgm.; on 50 per cent Dox's liquid, $40 \mathrm{mgm}$.

by heating. On the other hand, ageing of culture results in an increased stimulative offect over Fusarium mycelial growth.

Further work concerning the nature of the inhibitory anti-fungal metabolites of $B$. subtilis and the stimulatory factor of $B$. megatherium for Fusarium growth are still in progress. The former are probably of the nature of an antibiotic ${ }^{8}$ while the latter seems to be a growth factor. Difference in the rhizosphere microflora of wilt-resistant and susceptible cotton varieties might explain why Fusarium oxysporum fails to invade Ashmouni cotton roots while its pathogenicity is established on susceptible Karnak and Giza 26 cotton varieties.

Thanks are due to Prof. A. H. Montasir for his unfailing help.

Faculty of Science,

M. S. NATM*

A. M. Hussein

A'in Shams University,

Abbassia, Cairo.

- Present address: Shambat Agricultural Institute, P.0. Box 71, Khartoum North.

${ }^{3}$ Naim, M. S., Mahoud, S. A. Z., and Hussein, A. M., A'in Sham Sci. Bull., No. 1, 173 (1956).

Menon, K. P. V., Ann. Bot., 48 (1934)

Preseott, S. C., and Dunn, C., "Industrial Microbiology", 2nd Edn. (MCGraw-Hill Co., 1949).

\section{A Simple Technique for producing Fruit Bodies of Wood-destroying Basidiomycetes}

IN attempts to identify some of the many basidiomycete cultures isolated in our investigations of decay, we have tested a number of methods and have found that described here of the greatest value. It produces relatively large, identifiable fruit bodies from cultures representing a wide range of genera and families, and it has given consistent results in the hands of a number of workers, is not laborious, and requires no special equipment or materials.

The method involves establishing the culture to be identified on an enriched sawdust medium in a glass jar and then allowing it to grow through, and fruit on, a block of readily decayed wood incubated in diffuse daylight in a humid but not stagnant atmosphere.

The medium now used is a mixture of air-dry sawdusts (4-24 mesh) of seven timbers in the following proportions : Pinus radiata D. Don (sapwood), 25 ; Eucalyptus obliqua L'Herit. (sspwood), 25 ; $E$. diversicolor F. v. M., 10 ;. Acacia dealbata Link., 10 ; Nothofagus cunninghamii Oerst., 10 ; Rhizophora sp. 10 ; Ceratopetalum apetalum D. Don, 10. (This 